\title{
TRANSLATION STRATEGIES IN EUROPEAN AND CANADIAN FRENCH VERSIONS OF AN ANIMATED MOVIE'S ORIGINAL SOUNDTRACK
}

\author{
${ }^{1}$ Iona Stella LUMBAN TOBING, ${ }^{2}$ Myrna LAKSMAN-HUNTLEY \\ 1,2 Universitas Indonesia, Indonesia \\ 1 ionatobing@gmail.com, ${ }^{2}$ laksman.huntley@gmail.com \\ Article reçu le 26 octobre 2017 | révisé depuis le 30 octobre 2017 | accepté le 18 décembre 2017
}

\begin{abstract}
RÉSUMÉ. Comme un processus qui implique plusieurs langues, traduction peut être appliquée à diverses formes de médias, tels que des films, des livres et des chansons. Dans les traductions de film, ce processus parfois inclut non seulement les dialogues, mais aussi les chansons (bande originale). Cette étude vise à décrire l'application de stratégies de traduction dans deux versions françaises (européenne et canadienne) de bande-son de The Lion King II: Simba's Pride. Les chercheurs utilisent deux théories de stratégies d'application : traduction de la poésie (Lefevere, 1975) et traduction sur le plan lexical (Baker, 1992). Après l'analyse, les auteurs prennent une conclusion que les résultats variés de la traduction sont fortement influencés par interprétation et aucun problème de non-équivalence ne se trouve.
\end{abstract}

Mots-clés : bande-son, dessins animés, paroles, stratégies de la traduction.

\begin{abstract}
As a process that involves more than one language, translation can be applied in various forms of media, such as film, books and songs. In movie translations, this process sometimes includes not only the dialogues, but also the songs (original soundtrack). This study aims to describe the application of translation strategies in two French versions (European and Canadian) of The Lion King II: Simba's Pride's original soundtrack. The authors use two theories of translation strategies: Lefevere's poetry translation (1975) and Baker's word-level translation (1992). After the analysis was done, the author concluded that the various results of translation were heavily influenced by interpretation, but that no non-equivalence problem was found however.
\end{abstract}

Keywords: cartoon, lyrics, soundtrack, translation strategies. 


\section{INTRODUCTION}

A translator should be able to work on numerous texts, either narrative or lyrical, but translating a lyrical text such as a song, needs some knowledge in order to produce a good translation result. Marc (2015, p.8) identifies four forms of transcultural flows in the realm of popular music that can be considered as specific knowledge in song translation, these include a) the cultural reception of an imported song in its original version; b) a musical reprise with completely new lyrics and which bears almost no cultural traces of the original; c) the translation or adaptation of lyrics, and d) the emulation of imported musical styles or genres to different degrees.

Low (2013, p.229) stated that there are three approaches to song translations: translation to texts, adaptation, and replacement. Translation to texts is an "extensive transfer of material from the source text, with a reasonably high degree of semantic fidelity" (2013, p.231) and defined adaptation as "less equivalent to the source text than a translation, since the adaptor has made extensive and willful deviations from the original" (2013, p.231). On the other hand, replacement is "a song lyric created to be used with a pre-existing melody, yet manifesting no semantic transfer from the text previously sung to that melody" (2013, p.231).

Translation is not limited to merely standalone songs, but also ones that are part of another media, such as film. In this case, the songs are translated along with the film, since they are an original soundtrack (OST) and therefore inseparable. The translation process can be done by rewriting the lyrics in the target language and dubbing it to the scenes.

According to Aminoroaya and Amirian (2016, p.44) songs holds an important role in specific genres of movies, such as musicals and animations. They are used as a more expressive way to show the feelings and the thoughts of the characters. Songs are also able to shorten long stories and save the audience from boredom. In some genres, such as film musicals and animated movies, songs serve as narratives and have a plot-furthering function.

The argument stated above can also be a reason why the soundtrack of film is often translated instead of leaving them in their source language. Song translation, as defined by Franzon (2008, p.376), is a song (in the source language) that has its vital values (music, lyrics, and sung performance) reproduced in the target language. On the other hand, Low (2005, p.192-194) explains a 'singable' translation is one whose words can be easily sung with the original music.

Disney is one of the animation film companies whose soundtrack lyrics have been rewritten into various languages. The soundtracks in Disney's musical animation films usually hold an important part in the story. Edmonson stated that the songs are able to express the emotion and situation of the characters to the audience (cited by Warachananan \& Roongrattanakool, 2015, p.76). When sung by a certain character, soundtracks are able to explain their backstory and motivation.

This study aims to describe how the translation strategies in two French versions (European and Canadian) is applied. Additionally, this study also uncovers the difference between the French versions of lyrics translation. In the end of the study, the authors will be able to find which one is the closest equivalent to the source language, and whether the translator's interpretation has influenced the result.

There are two theories used in this study: André Lefevere's seven translation strategies of poetry (cited by Bassnett, 2002, p.86) covering phonemic translation, literal translation, metrical translation, poetry to prose, rhymed translation, blank verse translation, and interpretation; and Mona Baker's eight translation strategies on word level (1992, p.23-44) covering translation by a more general word (super ordinate), by a more neutral or less expressive word, by cultural substitution, by using a loan word or loan word plus explanation, by paraphrase using a related word, by paraphrase using unrelated words, by omission, and by illustration. 
Lefevere's theory is used based on the fact that a song is a 'poetry set to music' (Nida, 1964) in to consideration; while Baker's is used in order to find any nonequivalence problems between the source and target languages.

\section{METHOD}

The soundtrack's film chosen for this study is The Lion King II: Simba's Pride and its two French versions, one in European French and one in Canadian French. It is filled with African sensation, which is shown by the use of Zulu chanting and rhythmical instruments. This goes with where the story is taking place: a savannah in Africa.

The Lion King II: Simba's Pride (1998) is a sequel to The Lion King, released four years prior. It tells the story of Kiara, the princess of Pridelands, who lives in her father Simba's reign after Scar's death at the hands of his hyena followers. This film focuses on her journey towards love and choices, for she chooses Kovu, a son of Scar's former supporter, Zira.

The original soundtrack of the film consists of six songs; all of them are translated to two French versions, which produce various results. Some have exactly the same titles, despite the different lyrics. These songs were chosen because the film is commonly listed as the best Disney sequels, on comparison sites BuzzFeed (Nedd, 2014) and "The Top Tens". According to Lindsay (2016), some of the songs even have deeper meaning than their predecessor. The Lion King II: Simba's Pride (1998) is also one of the Disney sequels that have been released in the 'revival era' (1989-present, according to Puigderajols, 2001, p.60) that has a Canadian French version.

The songs listed below are analyzed by theories of translation strategies. Five of them are studied, firstly by Lefevere's translation strategies on poetry (cited by Bassnett, 2002, p.86) and secondly using Baker's translation strategies at word level (1992, p.23-44). The songs in this film consist of:

- "He Lives in You" (European and Canadian French versions: Il vit en toi)
- "We Are One" (European French: Nous sommes un, Canadian French: Une famille)

- "My Lullaby" (European French: Mon chant d'espoir, Canadian French: Voilà ma berceuse)

- "Upendi" (European and Canadian French versions: À Upendi)

- "One of Us" (European and Canadian French versions: L'un des nôtres)

- "Love Will Find a Way" (European French: L'amour nous guidera, Canadian French: L'amour saura gagner)

My Lullaby and its two translated versions were previously analyzed using Baker's theory. Thus, My Lullaby and its two translated versions will only be analyzed by Lefevere's in this study. In the former study, the authors were able to conclude that the Canadian French version had the closer equivalent with the source language despite more of the translation strategies being used. The results gained in it will also be mentioned within this study in order to obtain a thorough conclusion.

In this study, the authors used the qualitative method (literary review). This method is chosen because this study aims to describe a detailed analysis of the soundtrack of The Lion King II: Simba's Pride and its French versions and will include the songs' form (rhythmic and metrical patterns) and semantic. The authors started the analysis by dividing the lyrics into stanzas and compared the source text with both target languages. In order to find the meaning and to conduct the semantic analysis, the authors used the dictionaries Le Petit Robert (European French) and Multi Dictionnaire de la Langue Française (Canadian French), and the online dictionary Oxford (English). These dictionaries were chosen after taking their extensive vocabulary into consideration.

\section{RESULTS AND DISCUSSION}

The authors found translation strategies being applied 91 times in the European French version and 97 in the Canadian French version. After being sorted based on the strategies used, it was found that there were eight translation strategies applied: four (out of seven) of Lefevere's strategies and the same number of strategies 
(out of eight) from Baker's theory. Four Lefevere's translation strategies applied in the soundtrack are rhymed translation, metrical translation, blank verse translation, and interpretation. While the translation strategies in Baker's theory included translation by a more general word, translation by a more neutral or less expressive word, translation by paraphrase using a related word, and translation by omission.

In the analysis, the European French version will be referred to as the First Target Language (TL 1) and the Canadian French version as the Second Target Language (TL 2). English, as the source language, will be referred to as the Source Language (SL). This section will be divided based on the strategies found used in the soundtrack.

\section{Rhymed Translation}

Out of forty stanzas analyzed in this study, this translation strategy was applied eight times in TL 1 and eleven in TL 2. One of the examples of this strategy's application comes from the We are One refrain (TL 1: Nous sommes un, TL 2: Une famille). The first table below shows the application of this strategy.

Table 1. Rhythmic pattern analysis of We are One, Nous sommes un, and Une famille's refrain

\begin{tabular}{|c|c|c|c|c|c|}
\hline Source Language & Rhyme & $\begin{array}{l}\text { Target Language } 1 \\
\text { (European French) }\end{array}$ & Rhyme & $\begin{array}{l}\text { Target Language } 2 \\
\text { (Canadian French) }\end{array}$ & Rhyme \\
\hline $\begin{array}{l}\text { Family, family, } \\
\text { we are one }\end{array}$ & A & $\begin{array}{l}\text { Une famille, une } \\
\text { famille, tous unis }\end{array}$ & A & $\begin{array}{l}\text { Une famille, une } \\
\text { famille, nous }\end{array}$ & $\mathbf{A}$ \\
\hline $\begin{array}{l}\text { Family, family, } \\
\text { we are one }\end{array}$ & A & $\begin{array}{l}\text { Une famille, une } \\
\text { famille, pour la vie }\end{array}$ & A & $\begin{array}{l}\text { formons } \\
\text { Une famille, une } \\
\text { famille, nous } \\
\text { formons }\end{array}$ & A \\
\hline
\end{tabular}

In the source language, the rhyme appears in the second line of the stanza as repetition of the first. The same is the case in the TL 2, but in TL 1 the last line appears as une famille, une famille, pour la vie 'a family, a family, for life', that contrasts with the tous unis 'all unite' on the first line. Despite the difference, the rhyme stays.

Although there are more cases similar with Table 1, the limited amount of the application of this strategy indicates that the translators did not use this strategy regularly. Mostly, the translators did not maintain the same rhythmic pattern in the SL. The authors were able to discover two factors that caused this, which are:

1. The translators made new rhythmic patterns. This is done as the translators chose the words which have different rhythmic patterns with the SL. One of the examples that support this fact comes from the fourth stanza of He Lives in You (Il vit en toi in both target languages) (see table 2). In Table 2, translators of both target languages produce new rhythmic patterns that are different from the original. In TL $1, \mathrm{~A}-\mathrm{A}-\mathrm{B}-\mathrm{B}$ is changed into $A-A-A-A$, while in TL 2 it is changed to A-B-B-C. The translator's word choice is the reason of this change.

2. No rhythmic pattern in the first place. This results in a new pattern made by the translators. This occurs in the first stanza of Love will Find a Way (TL 1: L'amour nous guidera, TL 2: L'amour saura gagner) (see table 3). Other than the fact that there is no rhythmic pattern in the SL, this fact actually has the same point as the first one and the translators produce a completely new rhythmic pattern that is not taken from the SL. Also, the pattern is caused from the word choice of the translators. 
Table 2. Rhythmic pattern analysis of the fourth stanza of He Lives in You and Il vit en toi

\begin{tabular}{|c|c|c|c|c|c|}
\hline Source Language & Rhyme & $\begin{array}{l}\text { Target Language } 1 \\
\text { (European French) }\end{array}$ & Rhyme & $\begin{array}{l}\text { Target Language } 2 \\
\text { (Canadian French) }\end{array}$ & Rhyme \\
\hline $\begin{array}{l}\text { Wait! } \\
\text { There's no } \\
\text { mountain too great } \\
\text { Hear the words } \\
\text { and have faith } \\
\text { Have faith }\end{array}$ & $\begin{array}{l}\text { A } \\
\text { A } \\
\text { B } \\
\text { B }\end{array}$ & $\begin{array}{l}\text { Vois! } \\
\text { Rien n'est } \\
\text { trop beau pour toi } \\
\text { Tu vaincras si tu } \\
\text { crois } \\
\text { Tu crois }\end{array}$ & $\begin{array}{l}\text { A } \\
\text { A } \\
\text { A } \\
\text { A }\end{array}$ & $\begin{array}{l}\text { Oui! } \\
\text { Tu peux } \\
\text { aller plus } \\
\text { haut! } \\
\text { L'espoir est ton } \\
\text { flambeau } \\
\text { L'espoir }\end{array}$ & $\begin{array}{l}\text { A } \\
\text { B } \\
\text { B } \\
\text { C }\end{array}$ \\
\hline
\end{tabular}

Table 3. Rhythmic pattern analysis of the first stanza of Love will Find a Way, L'amour nous guidera, and L'amour saura gagner

\begin{tabular}{|c|c|c|c|c|c|}
\hline Source Language & Rhyme & $\begin{array}{l}\text { Target Language } 1 \\
\text { (European French) }\end{array}$ & Rhyme & $\begin{array}{l}\text { Target Language } 2 \\
\text { (Canadian French) }\end{array}$ & Rhyme \\
\hline $\begin{array}{l}\text { In a perfect world } \\
\text { One we've never } \\
\text { known } \\
\text { We would never } \\
\text { need to face the } \\
\text { world alone }\end{array}$ & $\begin{array}{l}\text { A } \\
\text { B } \\
\text { C }\end{array}$ & $\begin{array}{l}\text { Tout serait parfait } \\
\text { Si le monde était } \\
\text { Un monde de paix } \\
\text { comme il ne l'est } \\
\text { jamais }\end{array}$ & $\begin{array}{l}\text { A } \\
\text { A } \\
\text { A }\end{array}$ & $\begin{array}{l}\text { Dans un monde } \\
\text { parfait } \\
\text { On doit croire qu'un } \\
\text { jour } \\
\text { Il sera possible de } \\
\text { vivre à deux, } \\
\text { toujours }\end{array}$ & $\begin{array}{l}\text { A } \\
\text { B } \\
\text { B }\end{array}$ \\
\hline
\end{tabular}

\section{Metrical Translation}

This translation strategy is used more than rhymed translation, with a significant contrast. Out of forty stanzas analyzed in this study, the metrical translation strategy is applied 29 times in both target languages. The rest (eleven stanzas) have lines that do not maintain the meter from the source language. The change is usually done when the character does not appear or is far from the screen, so the difference is subtle. The example below is taken from the sixth stanza of Upendi ( $\grave{A}$ Upendi in both target languages).

Table 4. Metrical analysis of the sixth stanza of Upendi and $\grave{A}$ Upendi

\begin{tabular}{|c|c|c|c|c|c|}
\hline Source Language & Meter & $\begin{array}{l}\text { Target Language } 1 \\
\text { (European French) }\end{array}$ & Meter & $\begin{array}{l}\text { Target Language } 2 \\
\text { (Canadian French) }\end{array}$ & Meter \\
\hline $\begin{array}{l}\text { You can beat the } \\
\text { bush } \\
\text { Like there's no } \\
\text { to/mor/row } \\
\text { From } \\
\mathrm{Ta} / \mathrm{nga} / \mathrm{nyi} / \mathrm{ka} \text { to } \\
\mathrm{Ki} / \mathrm{li} / \mathrm{man} / \mathrm{ja} / \mathrm{ro} \\
\text { But you'll find } \\
\text { U/pen/di } \\
\text { wher/ever you are } \\
\text { Oh un/der/neath } \\
\text { the sun }\end{array}$ & $\begin{array}{c}5 \\
6 \\
11 \\
11\end{array}$ & $\begin{array}{l}\text { Tu pour/ras } \\
\text { march/er } \\
\text { Vo/ler comme un } \\
\text { oi/seau } \\
\text { Du Ta/nga/nyi/ka } \\
\text { au Ki/li/man/dja/ro } \\
\text { Tu trou/veras } \\
\text { U/pen/di } \\
\text { par/tout dans ta vie } \\
\text { Oui ! Sous le grand } \\
\text { soleil }\end{array}$ & $\begin{array}{c}5 \\
6 \\
11 \\
11 \\
6\end{array}$ & $\begin{array}{l}\text { Tu peux tourn/er } \\
\text { en rond } \\
\text { Sans ja/mais de } \\
\text { re/pos } \\
\mathrm{Du} \mathrm{Ta/nga/nyi/ka} \\
\text { au Ki/li/man/ja/ro } \\
\text { Si tu cherches } \\
\mathrm{U} / \text { pen/di, } \\
\text { il est avec toi } \\
\underline{\text { Il suit le }} \\
\underline{\text { so/leil }}\end{array}$ & $\begin{array}{c}5 \\
6 \\
11 \\
11 \\
\underline{5}\end{array}$ \\
\hline
\end{tabular}

In the last line, the authors found a metrical difference between SL and TL 2. The Canadian French version omitted the exclamation oh that belongs in the SL (which is translated to oui 'yes' in TL 1). When this part is sung, Rafiki (the singer) is swinging so the difference is not visible. Like the rhymed translation strategy, the metrical difference is also influenced by the translators' word choice. 


\section{Blank Verse Translation}

While rhymed and metrical translation deal with the physical side of the poem (in this case, a song), blank verse translation focuses on the semantic side. Out of forty stanzas analyzed in this study, this strategy was applied seven times by the TL 1 translator and seventeen times by the TL 2 translator. One of the examples of this strategy's application is taken from the second stanza of He Lives in You.

Table 5. Second stanza of He Lives in You and Il vit en toi

\begin{tabular}{l|l|l}
\hline \multicolumn{1}{c|}{ Source Language } & \multicolumn{1}{|c}{$\begin{array}{c}\text { Target Language 1 } \\
\text { (European French) }\end{array}$} & \multicolumn{1}{|c}{$\begin{array}{c}\text { Target Language 2 } \\
\text { (Canadian French) }\end{array}$} \\
\hline Night & Nuit! & Nuit ! \\
And the spirit of life & Et l'esprit de la vie & Et toute la soif de vivre \\
Calling & T'appellent & Mappelle \\
Mamela & Mamela & \\
\hline
\end{tabular}

In Table 5, both target language translators use close equivalent in the translated versions. Even so, not all parts are translated literally. In TL 1, the third line is almost translated literally, but the translator adds the word te 'you' in appellent 'calling'. The addition might have been made based on the fact that the verb appeller 'to call' is transitive. It can be concluded that the European French translator gave a similar equivalent, but added something that didn't completely change the line itself.

On the other hand, TL 2 adds the word soif 'thirst' to translate the word spirit in SL. Literally, soif means besoin de boire 'the need to drink', but can also be seen as desir impérieux 'strong desire'. When accompanied by the words of life and de vivre 'of life', soif de vivre describes an irresistible desire to keep living, and can be considered a close equivalent to spirit of life. The authors concluded that even though the word choice is slightly different, it remains a close equivalent to the source text.

\section{Interpretation}

This translation strategy is used the most in the soundtrack. Out of forty stanzas analyzed in this study, this strategy is applied 33 times in TL 1 and 23 times in TL 2. The high number of the application shows that both target language translators have freedom in translating the songs. One of the examples of this strategy's application comes from the first stanza of One of Us ( $L^{\prime}$ 'un des nôtres in both target languages).

Table 6. First stanza of One of us and L'un des nôtres

\begin{tabular}{|c|c|c|}
\hline Source Language & $\begin{array}{l}\text { Target Language } 1 \\
\text { (European French) }\end{array}$ & $\begin{array}{l}\text { Target Language } 2 \\
\text { (Canadian French) }\end{array}$ \\
\hline $\begin{array}{l}\text { Deception } \\
\text { Disgrace } \\
\text { Evil as plain as the scar on } \\
\text { his face } \\
\text { Deception! An outrage! } \\
\text { Disgrace! For shame! } \\
\text { He asked for trouble the } \\
\text { moment he came }\end{array}$ & $\begin{array}{l}\text { Trahison! } \\
\text { Disgrâce ! } \\
\text { L'esprit du mal est marqué sur } \\
\text { sa face } \\
\text { Trahison! Quel outrage! } \\
\text { Disgrâce ! Et violence! } \\
\text { Il n'est que nuisance depuis sa } \\
\text { naissance }\end{array}$ & $\begin{array}{l}\text { Déception! } \\
\text { Trahison! } \\
\text { Il a toujours attiré les ennuis } \\
\text { Déception ! Imposteur! } \\
\text { Trahison! La honte! } \\
\text { Il est le mal, il en porte sa } \\
\text { marque }\end{array}$ \\
\hline
\end{tabular}

The interpretation of this stanza comes from certain lines, such as the first and last ones. In the first line, TL 1 uses trahison to translate deception, while TL 2 uses déception. This word, in its source language, means the action of deceiving someone. On the other hand, trahison means action de trahir, de manquer au devoir de fidélité 'the act of betrayal, lacking the obligation of fidelity' while déception means espoir non realisé, insatisfaction 'unrealized hope, dissatisfaction'. From this, it shows that even though the word déception used in TL 2 has the impression of being closer to the SL, the meaning is slightly 
different. While deception and trahison refers to fraud and betrayal, déception is more about disappointment and displeasure.

In the last line, the TL 1 translator uses il n'est que nuisance depuis sa naissance 'he's merely a nuisance since he was born'. Meanwhile, TL 2 uses il est le mal, il en porte sa marque 'he is evil, he has that evil mark'. These two sentences are used to translate he asked for trouble the moment he came'. In TL 1, the translator used the words nuisance and naissance to translate trouble and came. The two words are used to emphasize the fact that Kovu was not only trouble since he came to Pridelands, but that he has been a burden since he was born, which results in a more vicious and expressive translation than its original line.

On the other hand, TL 2 adds marque 'mark' in its translation. The translator remakes this line and changes it into a completely different one. This addition gives a reference to the newly-received scar on Kovu's eyes. The mark given by Zira looks exactly like Scar's, and is considered a mark of evil. This also shows that the translation result is influenced by the story behind the soundtrack.

\section{Baker's Translation Strategies}

In this study, Baker's translation strategies at word level become part of interpretation since it is considered a more detailed analysis of the theory. The authors did not find any non-equivalence problems in this study, thus the application of these strategies are applied because of translators' interpretation. Out of forty stanzas analyzed in this study, the authors found the strategies used 14 times in TL 1 and 17 times in TL 2. The strategies used are translation by a more general word, translation by a more neutral or less expressive word, translation by paraphrase using a related word, and translation by omission.

Below is an example of Baker's theory application. This is taken from the third line of fourth stanza in One of Us. In this line it was found that the translation strategy had been used by using a general word, although in different forms. This line is a mockery on
Kovu who is unable to stand against his own fate that his mother has chosen for him.

SL: Helpless to defy his fate

TL 1: Il ne peut changer sa vie

TL 2: Il est seul, c'est son destin

In TL 1, the translator used vie 'life' (in il ne veut pas changer sa vie 'he can't change his life') in order to translate fate (helpless to defy his fate). Vie means fait de vivre 'going on through life' while fate is presumed cause, force that predetermines events. From here, it can be seen that vie refers to Kovu's life. It becomes a more general equivalent than fate that specifically refers to Kovu's destiny to become Simba's killer.

In TL 2, seul 'alone' is the example of translation by a more general word application. The translator uses this word to translate helpless. Seul means être sans compagnie, séparé des autres 'no companion, separated from the others' while helpless is defined as unable to defend oneself. From this, it can be seen that seul gives a more general description of Kovu's loneliness than helpless which emphasizes Kovu's weak will to go against his mother's wishes.

Baker's translation strategies are not commonly used, rather instead applying these strategies, both target languages mostly go against them. In the soundtrack, the authors find more specific and/or more expressive words than the SL equivalent. The example below comes from a line in $M y$ Lullaby (TL 1: Mon chant d'espoir, TL 2: Voilà ma berceuse).

SL: Uh-I mean, precious little thing!

TL 1: Je veux dire "gentil petit chat"

This line is sung when Nuka, Kovu's older brother, was being scornful towards his sleeping brother, only to be stopped by Vitani's (Kovu's older sister) glare. The translator uses the word gentil petit chat 'nice little cat' to translate precious thing. The word chat becomes a more specific equivalent to the word thing. It makes a direct reference to Kovu's physical appearance as a cub, and therefore a part of the felines.

\section{CONCLUSION}

As mentioned above, the authors found eight translation strategies used in two French versions of The Lion King II: Simba's 
Pride's soundtrack. The eight translation strategies consist of four Lefevere's poetry translation strategies and four Baker's translation strategies on word level. The amount of strategies applied does not have a stark difference in both target languages.

Lefevere's interpretation is the translation strategy most often used (33 times in TL 1, 23 times on TL 2). Blank verse translation follows close second with 7 times in TL 1 and 17 times in TL 2. At the same time, none of the target language applied a lot of rhymed translation strategy (8 times in TL 1, 11 times in TL 2), but both target languages applied the same number of occasions of metrical translation strategy (29 times).

The few occasions of rhymed translation applied and the rather many occasions of metrical translation that both target language translators mostly maintained the metrical pattern rather than the rhyme in the stanzas. The meter maintained in the SL is caused by the obligation of adapting the lyrics with its musical aspect. Also, the translators have to match the lyrics sung with the oral movement of the characters. These aspects have to be taken to consideration in order to produce an exact translation, in both audio and visual.

On the other hand, rhymed translation is less used by the translators. Mostly, they made a whole new rhythmic pattern, whether there was a rhythmic pattern in the source language or not. This was also influenced by the word choice of the translators, and shows that reproducing the message in the soundtrack plays a more important role than maintaining the same rhyme in the target languages.

In the semantic side, there are two Lefevere's theories applied: interpretation and blank verse translation. In contrast with rhymed and metrical translation strategies, these semantic-related strategies are contradictory. While blank verse translation emphasizes the usage of a closer equivalent, interpretation is a strategy used when the translation differs based on what can be interpreted by the translator.
As elaborated in the Result and Discussion, interpretation is the strategy most used in both target languages, but despite being translated into French, both target languages show different results. These results might occur because of different emphasis and the shift of meaning. In addition, the authors also found two strategy applications in a stanza. The second strategy is Baker's translation strategies on word level, which becomes a more detailed study on the stanza.

Baker's strategy becomes part of interpretation since it changes or omits a certain part at a lower level (word). The authors did not find any non-equivalence problems in the soundtrack analyzed, thus the theory was applied because of the word choice of the translators. Therefore, the stanzas that have more than one strategy applied have a more specific analysis.

From this study, the authors were able to conclude that the translators have freedom in reproducing the soundtrack. Even so, TL 2 (Canadian French) has made a closer translation to the SL. Despite that, the interpretation applied in the soundtrack is not caused by the absence of closer equivalents in the target language, but more because of the word choice of the translators. The different choice of words is influenced by the translator's interpretation of the text outside the soundtrack, which is the story of the film itself.

This study might be beneficial for people who have an interest in the world of translation, particularly translation of song lyrics and soundtracks in order to see whether the message in a song is properly transferred to the target language. We should do a further study in translation strategies that focuses on the translators' or audiences' backgrounds, and additionally study a song by analyzing the musical aspect.

\section{ACKNOWLEDGEMENTS}

On this occasion, the authors would like to express their acknowledgments to all those who have helped the realization of this article. Their gratitude also goes to Faculty of Humanities, Universitas Indonesia for the preliminary study that hopefully will be 
published in a short time. Last but not least, the authors also like to thank Francisola for the opportunity given to publish this article.

\section{REFERENCES}

Aminoroaya, S and Amirian, Z. (2016). Investigating the Translation of Songs in Persian Dubbed Animated Movies. Journal of Translation and Interpretation, 10(2), 44-68.

Baker, M. (1992). In other words: A course book on translation. London: Routledge.

Bassnett, S. (2002). Translation studies (3 ${ }^{\text {rd }}$ ed.). London: Routledge.

Franzon, J. (2008). Choices in song translation: Singability in print, subtitles and sung performance. The Translator, 14(2), 373-399.

Lindsay, D. (2016). You might wrongly disagree but The Lion King 2 is better than the original and here's why. Retrieved from http://metro.co.uk/2016/02/13/youmight-wrongly-disagree-but-the-lionking-2-is-better-than-the-original-andheres-why-5676939/

Low, P. (2005). The Pentathlon approach to translating songs. In Gorlée, D. L. (2005). Song and Significance: Virtues and Vices of Vocal Translation.
Amsterdam and New York: Rodopi. 185-212.

Low, P. (2013). When songs cross language borders. The Translator, 19(2), 229-244.

Marc, I. (2015). Travelling songs: on popular music transfer and translation. Journal of the International Association for the Study of Popular Music, 3-21.

Nedd, A. (2014). An Authoritative Ranking of Disney Sequels. Retrieved from https://www.buzzfeed.com/alexisnedd /an-authoritative-ranking-of-disneysequels?utm_term=.vvygxZAQR\#.thXJ p6j07

Nida, E. A. (1964). Toward a science of translating: with special reference to principles and procedures involved in Bible translating. Leiden: Brill.

Puigderajols, A. M. R. (2001). A linguistic study of the magic in Disney lyrics. Barcelona: Barcelona University.

Warachananan, P. \& Roongrattanakool, D. (2015). A study of translation strategies in the translation of songs in Walt Disney's animated feature films into Thai versions. Retrieved from http://gs.nsru.ac.th/files/5/7\%20ปณณภ า\% $20 \% 20$ วรชนานันท์.pdf 